\title{
A natural herbal remedy modulates angiogenic activity of bronchoalveolar lavage cells from sarcoidosis patients
}

\author{
DOROTA M. RADOMSKA-LEŚNIEWSKA ${ }^{l}$, EWA SKOPIŃSKA-RÓŻEWSKA ${ }^{2,3}$, URSZULA DEMKOW \\ JAROSŁAW JÓŹWIAK ${ }^{1}$, MAŁGORZATA SOBIECKA ${ }^{5}$, BARBARA JOANNA BAEAN \\ 'Department of Histology and Embryology, Biostructure Centre, Medical University of Warsaw, Warsaw, Poland \\ ${ }^{2}$ Department of Pathomorphology, Biostructure Centre, Medical University of Warsaw, Warsaw, Poland \\ ${ }^{3}$ Military Institute of Hygiene and Epidemiology, Warsaw, Poland \\ ${ }^{4}$ Department of Laboratory Diagnostics and Clinical Immunology of Developmental Age, Medical University of Warsaw, Warsaw, Poland \\ ${ }^{5}$ I Department of Lung Diseases, National Institute of Tuberculosis and Lung Diseases, Warsaw, Poland \\ ${ }^{6}$ Department of Immunology, Biochemistry, and Nutrition, Medical University of Warsaw, Warsaw, Poland
}

\begin{abstract}
Sarcoidosis is a systemic inflammatory disease with abnormally high angiogenic activity of inflammatory cells. Reumaherb preparation consisting of three herbs: Echinacea purpurea, Harpagophytum procumbens, and Filipendula ulmaria, and it exerts anti-inflammatory, antioxidant, and analgesic activity and stimulates regenerative and immunological processes.

The aim of this paper was to estimate the effect of Reumaherb on immunological angiogenesis induced by bronchoalveolar lavage (BAL) cells collected from six patients with sarcoidosis and grafted into Balb/c mice skin. After grafting, the animals were fed for three days with 0.6 or $1.2 \mathrm{mg}$ of Reumaherb (calculated from recommended human daily dose) daily, suspended in $40 \mu$ of water, or $40 \mu \mathrm{l}$ of water alone (control group).

A significant reduction of newly formed blood vessels was obtained in four cases for $1.2 \mathrm{mg}$ and in three cases for $0.6 \mathrm{mg}$ daily dose of this remedy. Thus, we hypothesise that Reumaherb promotes anti-angiogenic activity and may potentially be used in diseases associated with excessive blood vessel formation.
\end{abstract}

Key words: sarcoidosis, bronchoalveolar lavage cells, BAL, herbal remedy, leukocyte-induced angiogenesis, LIA, murine skin.

(Cent Eur J Immunol 2016; 41 (1): 25-30)

\section{Introduction}

Therapy of chronic inflammatory diseases is often difficult and long-lasting, so it may be associated with serious side effects (especially in the case of corticosteroids and nonsteroidal anti-inflammatory drugs). There is a need for safer medicines that could be applied in disorders with prolonged activation of the immune system. Sarcoidosis, a chronic systemic disease, belongs to the group of the most frequent interstitial lung diseases. Its pathogenesis involves immunological disturbances with characteristic granulomas forming in affected organs. The disease affects mainly young people [1].

Chronic inflammation is always accompanied by angiogenesis. Many key stimulatory mediators for angiogenesis, such as vascular endothelial growth factor (VEGF), fibroblast growth factor $\mathrm{b}$ (bFGF), transforming growth factor (TGF)- $\alpha$, IL-1, IL-6, and IL-8, platelet-derived growth factor (PDGF), and tumour necrosis factor $\alpha$ (TNF- $\alpha$ ) show pro-inflammatory activity, while angio-inhibitory mediators [e.g. IL-10, IL-12, interferon (IFN)- $\alpha$, IFN- $\gamma$, and TGF- $\beta$ ] have anti-inflammatory potential. In normal conditions, both processes are induced locally for a short time to destroy harmful factors, e.g. pathogens, and then subside, before regeneration of affected tissue. The long-term and systemic character of both processes usually has serious medical consequences. Such pathological conditions can be observed in sarcoidosis. Elevated levels of angiogenesis have been shown in sarcoidosis patients $[2,3]$.

Natural medicine offers many preparations of plant origin, with anti-inflammatory and anti-angiogenic action. Echinacea purpurea is one of the herbs with anti-angio-

Correspondence: Barbara Joanna Bałan, Department of Immunology, Biochemistry and Nutrition, Medical University of Warsaw,

Pawinskiego 3 A, 01-106 Warsaw, Poland, e-mail: vhm@post.pl

Submitted: 25.01.2016, Accepted: 10.02.2016 
genic, antioxidant, anti-inflammatory, and immunostimulatory properties [4].

Filipendula ulmaria, besides its anti-inflammatory and antioxidative action, reveals hepatoprotective properties. Harpagophytum procumbens, a herb used in South African medicine, exhibits anti-rheumatic, analgesic, and anti-inflammatory activity and was successfully used for alleviation of pain and mobility improvement in musculoskeletal conditions. These three herbs are components of Reumaherb preparation. Reumaherb displays anti-inflammatory, antioxidant, and analgesic activity and stimulates regenerative and immunological processes. It was successfully used in the treatment of degenerative disorders of joints and musculoskeletal disorders, as well as diseases with inflammatory pathogenesis $[5,6]$.

Formulations with anti-angiogenic properties could have a favourable therapeutic effect in diseases with elevated levels of angiogenesis, including sarcoidosis.

In order to test this hypothesis, in this paper we evaluate the effect of Reumaherb on immunological angiogenesis induced by bronchoalveolar lavage (BAL) cells collected from patients with sarcoidosis.

\section{Material and methods}

\section{Patients' characteristics}

The study population consist of seven patients (three women and four men), with diagnosed pulmonary sarcoidosis, who underwent bronchoscopic bronchoalveolar lavage (BAL) for clinical reasons. The diagnosis of the disease was based on clinical, radiological, and histopathological examination. According to X-ray findings, sarcoidosis was classified as stage I process (acute phase) in four patients, and stage II/III in three patients (chronic phase).

None of the patients was receiving oral or inhaled steroids at the time of BAL or during the previous three months.

\section{Bronchoalveolar lavage}

Bronchoalveolar lavage was performed in all patients for diagnostic purposes, with informed consent. The control group consisting of healthy subjects was not formed for ethical reasons, instead literature data of healthy control group presented by John et al. [7] were used for comparison purposes. Bronchoalveolar lavage was performed by standard procedure [8]. Fifty millilitres of sterile $0.9 \%$ saline solution (Natrium chloratum $0.9 \%$ inj., Polfa, Lublin) at room temperature was instilled through a flexible fibreoptic bronchoscope four times, to a total volume of $200 \mathrm{ml}$, with harvesting of the fluid under immediate gentle vacuum. Recovered BAL was filtered trough sterile gauze, and the cells were counted. The fluid was then centrifuged at $400 \mathrm{~g}$ for 10 minutes. Cells were $>90 \%$ viable as assessed by trypan blue exclusion. Cytospinned smears of BAL cells were stained with May-Grunwald-Giemsa differential staining method and evaluated by counting a minimum of 600 cells. CD4- and CD8-positive cells were identified by specific monoclonal antibody (LSAB+ Kit, DAKO, Denmark), according to the detailed description provided by the manufacturer. The cells were counted under a light microscope at a final magnification of $1000 \times$.

\section{Angiogenesis assay}

Angiogenesis test was performed according to Sidky and Auerbach [9] with Skopińska-Różewska et al. modification [10]. Angiogenesis test was performed based on BAL cells achieved from six sarcoidosis patients. Balb/c inbred mice (eight weeks old) from the Polish Academy of Sciences breeding colony were anaesthetised intraperitoneally with $3.6 \%$ chloral hydrate (Sigma-Aldrich, USA; $0.1 \mathrm{ml}$ per $10 \mathrm{~g}$ of body mass) before performing injections. Both flanks of each mouse were shaved with a razor and then 2-3 intradermal injections of $0.05 \mathrm{ml}$ of BAL cells suspension $\left(10 \times 10^{6} / \mathrm{ml}\right)$ were performed on each flank. Cell suspensions were supplemented with $0.05 \mathrm{ml} /$ $\mathrm{ml}$ of $0.01 \%$ trypan blue in order to facilitate subsequent recognition of injection sites.

Tested animals were fed Reumaherb preparation (Herbapol, Poznań; tablets $100 \mathrm{mg}$ ) (0.6 or $1.2 \mathrm{mg}$ suspended in $40 \mu \mathrm{l}$ of water) or $40 \mu \mathrm{l}$ of water (controls) for three days with use of an Eppendorf pipette. After 72 hours, the mice were treated with a lethal dose of Morbital (Biowet, Puławy, Poland).

All newly formed blood vessels (thin, with ramifications, and extending to the injection site) were identified and counted under a dissection microscope on the inner skin surface, at magnification of $6 \times$, in the $1 / 3$ central area of the microscopic field.

All experiments were accepted and supervised by the local Ethical Committee.

\section{Statistical analysis}

All data are presented as mean \pm SEM.

Angiogenic activity was calculated as the mean number of newly formed blood vessels. Differences between the groups were calculated by two-way ANOVA followed by Bonferroni post-test (GraphPadPrism software, Inc.; version 5). The differences were considered significant at $p$ value $<0.05$.

\section{Results}

\section{Bronchoalveolar lavage characteristics}

Sarcoidosis patients presented BAL lymphocytosis and increase of CD4/CD8 ratio when compared to the control group of healthy subjects presented by John et al. [7]. The results are shown in Fig. 1 and Table 1. 


\section{Angiogenic activity of bronchoalveolar lavage cells}

Analysis of angiogenesis test was performed based on BAL cells originating from six sarcoidosis patients.

Reumaherb preparation used at the dose of $1.2 \mathrm{mg}$ decreased angiogenic activity of BAL cells from four patients, and no effect was observed in two patients (Fig. 2, Table 2).

Angiogenic activity of BAL cells was also modulated when $0.6 \mathrm{mg}$ of remedy was used. BAL cells from three patients presented decreased the level of angiogenic activity, while angiogenic properties of cells from one patient were increased. BAL cells from another two patients from this group showed angiogenic response that did not differ from the control level (Fig. 2, Table 2).

\section{Discussion}

Sarcoidosis is a systemic inflammatory disease with abnormally high angiogenic activity of inflammatory cells [2]. The morphological pattern of BAL cells obtained from our patients (lymphocytosis and increase of CD4/CD8 ratio, Fig. 1, Table 1) is usually observed in the course of sarcoidosis [8]. The phenomenon of increased angiogenesis observed in BAL fluid from patients with sarcoidosis is probably caused by changes of macrophage phenotype/ function. According to Chorostowska-Wynimko et al. [11], non-CD4 ${ }^{+}$and non-CD8 ${ }^{+}$cells are the main source of angiogenic activity of BAL cells from sarcoidosis patients. Recent years have brought new insights into the role of macrophages in sarcoidosis [12-14]. It has been shown that M2 type macrophages are present within the sarcoidosis nodules, which, unlike M1 macrophages (IFN- $\gamma$-activat-

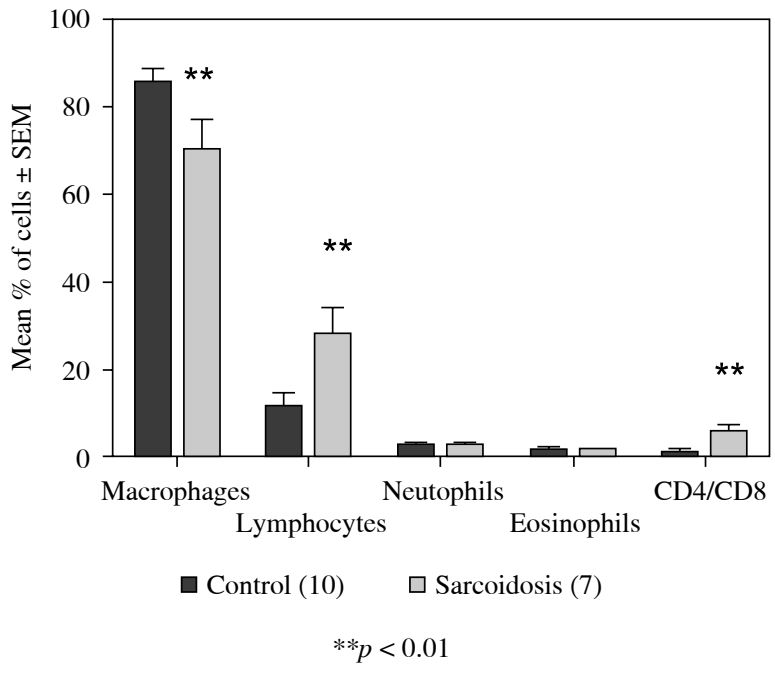

Fig. 1. Morphological characteristic of BAL cells derived from pulmonary sarcoidosis patients and control group of healthy subject (data of healthy subjects according to John et al. [5])

ed), are activated alternatively by IL-4, IL-13, and release VEGF. Elevated expression of VEGF in granulomas and macrophages isolated from sarcoidosis patients was observed by Tolnay et al. [15]. Sera isolated from non-pulmonary sarcoidosis patients also show increased levels of VEGF [16]. Our previous studies have shown that the levels of pro-angiogenic cytokines, matrix metalloproteinase (MMP-9), and IL-8 are elevated in BAL of patients with sarcoidosis. Furthermore, a strong correlation between these cytokines and IL-10 in the BAL of these patients

Table 1. A comparison of BAL characteristics of studied and control group - statistical analysis

\begin{tabular}{lcccc}
\hline Two-way ANOVA & & & \\
\hline Source of variation & \% of total variation & $\boldsymbol{P}$-value & $\boldsymbol{P}$ value summary & Significant? \\
\hline Interaction & 2.68 & $<0.0001$ & $* * *$ & yes \\
\hline Group of people & 0.03 & 0.5471 & NS & no \\
\hline BAL cells \% & 90.28 & $<0.0001$ & $* * *$ & yes \\
\hline Bonferroni posttests & & & $\boldsymbol{P}$-value & $* *$ \\
\hline Control (10) vs. sarcoidosis (7) & & $\boldsymbol{t}$ & $* 0.01$ & $* *$ \\
\hline BAL cells \% & Difference & 3.626 & $<0.01$ & NS \\
\hline Macrophages & -15.2 & 3.816 & $>0.05$ & NS \\
\hline Lymphocytes & 16 & 0.02385 & $>0.05$ & $* 0.01$ \\
\hline Neutrophils & 0.1 & 0.02385 & unpaired $t$ test & \\
\hline Eosinophils & -0.1 & 1.162 & & \\
\hline CD4/CD8 & 4.870 & & & \\
\hline
\end{tabular}




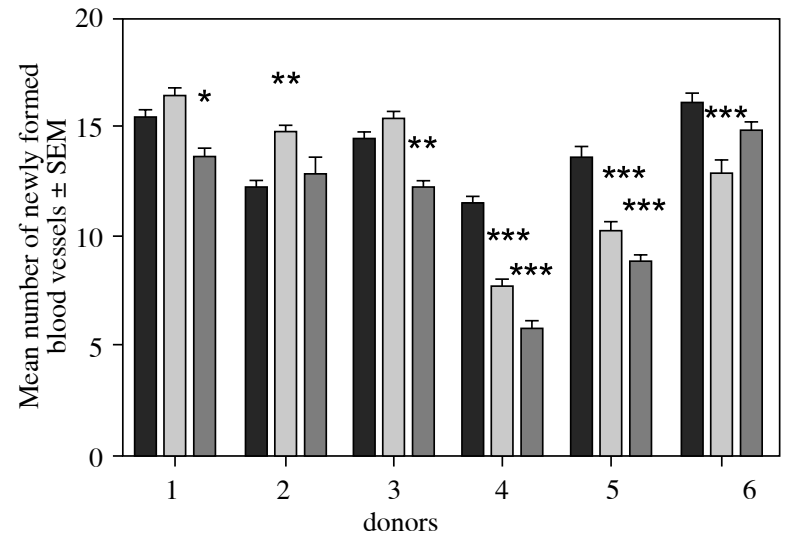

Total number of LIA tests: 189

- Placebo $\square$ Reumaherb $0.6 \mathrm{mg} \quad \square$ Reumaherb $1.2 \mathrm{mg}$

$$
\begin{gathered}
* p<0.05 \\
* * p<0.01 \\
* * * p<0.001
\end{gathered}
$$

Fig. 2. The influence of Reumaherb on angiogenic activity of BAL cells derived from sarcoidosis patients implicates the significance of angiogenesis in the patho genesis of sarcoidosis [8]. Therefore, formulations with antiangiogenic properties could have favourable therapeutic effect in the disease.

The results of the present paper demonstrate the antiangiogenic activity of Reumaherb in some patients (Fig. 2, Table 2). A dose of $1.2 \mathrm{mg}$ showed stronger anti-angiogenic properties than $0.6 \mathrm{mg}$. The different neovascular reaction of BAL cells to Reumaherb seems to be related to sarcoidosis stage (four patients in the acute phase, two patients in the chronic phase). Zielonka et al. [3] demonstrated the differences between neovascularisation levels induced by sera from sarcoidosis patients at various stages of disease. That is why the present study should be expanded to a larger cohort of sarcoidosis patients to confirm the anti-angiogenic properties of Reumaherb.

An anti-angiogenic effect of Reumaherb applied orally $(1.2 \mathrm{mg})$ to mice was seen also when mononuclear cells (MNC) from healthy donors were preincubated for 24 hours with sera from sarcoidosis patients and then injected into murine skin to induce neovascular reaction [5]. Furthermore, Reumaherb (1.2 mg, p.o. fed to mice) exerted

Table 2. A comparison of the Reumaherb influence on angiogenic activity of BAL cells derived from sarcoidosis patients

\begin{tabular}{|c|c|c|c|c|}
\hline \multicolumn{5}{|l|}{ Two-way ANOVA } \\
\hline Source of variation & $\%$ of total variation & $P$-value & $P$-value summary & Significant? \\
\hline Interaction & 15.61 & $<0.0001$ & $* * *$ & yes \\
\hline Drug & 10.91 & $<0.0001$ & $* * *$ & yes \\
\hline Donors of BAL & 58.1 & $<0.0001$ & $* * *$ & yes \\
\hline \multicolumn{5}{|l|}{ Bonferroni posttests } \\
\hline \multicolumn{5}{|c|}{ Placebo vs. Reumaherb 0.6 mg } \\
\hline Donors of BAL & Difference & $t$ & $P$-value & Summary \\
\hline Donor 1 & 1.0 & 1.878 & $>0.05$ & NS \\
\hline Donor 2 & 2.5 & 5.035 & $<0.01$ & $* *$ \\
\hline Donor 3 & 0.9 & 1.624 & $>0.05$ & $* *$ \\
\hline Donor 4 & -3.9 & 7.226 & $<0.001$ & $* * *$ \\
\hline Donor 5 & -3.4 & 5.451 & $<0.001$ & $* * *$ \\
\hline Donor 6 & -3.3 & 5.561 & $<0.001$ & $* * *$ \\
\hline \multicolumn{5}{|c|}{ Placebo vs. Reumaherb $1.2 \mathrm{mg}$} \\
\hline \multicolumn{5}{|l|}{ Donors of BAL } \\
\hline Donor 1 & -1.8 & 3.095 & $<0.05$ & $*$ \\
\hline Donor 2 & 0.6 & 1.127 & $>0.05$ & NS \\
\hline Donor 3 & -2.2 & 3.97 & $<0.01$ & $* *$ \\
\hline Donor 4 & -5.8 & 10.75 & $<0.001$ & $* * *$ \\
\hline Donor 5 & -4.7 & 7.828 & $<0.001$ & $* * *$ \\
\hline Donor 6 & -1.3 & 2.566 & $>0.05$ & NS \\
\hline
\end{tabular}
- statistical analysis 
anti-inflammatory and anti-angiogenic activity on MNC from rheumatoid arthritis patients. These observations encourage the use of Reumaherb as adjuvant medicine in the group of diseases with high level of angiogenesis [5, 6].

Furthermore, our previous studies have shown that Reumaherb and Immunal Forte (dry extract of Echinacea purpurea) decrease neovascular reaction in murine skin after grafting human kidney cancer cells or their homogenates. Also, neovascular reaction induced in murine skin by syngeneic L-1 sarcoma cells, as well as VEGF concentration in L1 sarcoma tumour tissue, were diminished by the preparation derived from Echinacea purpurea [17-19]. Elevated angiogenic activity of BAL cells from sarcoidosis patients was also reduced by natural preparation containing coastal salt-lake mud distillate with cinnamic acid and coumarin (FIBS). In this experimental model, mice were injected homogenates of BAL cells or supernatants from 48-hour cultures of these cells with FIBS [20].

Both Reumaherb and FIBS belong to natural plant antioxidants that downregulate angiogenesis in vitro and in vivo [5, 20, 21]. Another antioxidant synthetic compound, $\mathrm{N}$-acetylcysteine, reduced expression of pro-angiogenic factors (IL-8, MMP-9 and intercellular adhesion molecule 1) by BAL cells isolated from interstitial lung disease patients, including sarcoidosis [22, 23].

Taken together, Reumaherb, as well as its anti-inflammatory activity, may also display anti-angiogenic properties. Considering its capability to decrease neovascularisation, this remedy could probably be effective as an adjuvant medicine in the treatment of disorders with abnormally high angiogenesis. However, in order to confirm the usefulness of Rheumaherb in anti-angiogenic treatment of sarcoidosis patients, our preliminary findings should be extended to a larger number of cases.

\section{The authors declare no conflict of interest.}

\section{References}

1. Baughman RP, Culver DA, Judson MA (2011): A concise review of pulmonary sarcoidosis. Am J Respir Crit Care Med 183: 573-581.

2. Zielonka TM (2009): Angiogenesis in interstitial lung diseases. Pneumonol Alergol Pol 77: 52-60.

3. Zielonka TM, Demkow U, Białas B, et al. (2007): Modulatory effect of sera from sarcoidosis patients on mononuclear cells-induced angiogenesis. J Physiol Pharmacol 58 (suppl. 5): 753-766

4. Skopińska-Różewska E, Sommer E, Bałan B, et al. (2010): The in vivo effect of dry hydro-alcoholic extract of Echinacea purpurea on angiogenic activity of human blood mononuclear cells. Cent Eur J Immunol 35: 223-226.

5. Radomska-Leśniewska DM, Demkow U, Chorostowska-Wynimko J, et al. (2006): Immunotropowe działanie złożonego preparatu roślinnego Reumaherb. In: Naturalne i syntetyczne modulatory odpowiedzi immunologicznej i angiogenezy (materiały konferencyjne). Siwicki A, Skopińska-Różewska E (eds.). SPW Edycja, Olsztyn 2006; 49-59.

6. Radomska-Leśniewska DM, Skopiński P, Bałan BJ, et al. (2015): Angiomodulatory properties of Rhodiola spp. and other natural antioxidants. Cent Eur J Immunol 40: 249-262.

7. John M, Oltmans U, Fietze I, Witt C (2001): Increased production of matrix metalloproteinase- 2 in alveolar macrophages and regulation by interleukine-10 in patients with acute pulmonary sarcoidosis. Exp Lung Res 68: 55-67.

8. Radomska-Leśniewska DM, Sobiecka M, ChorostowskaWynimko J, et al. (2003): Relationship between IL-8, IL-10 and MMP-9 level and morphological pattern of BAL fluid in interstitial lung diseases patients. Cent Eur J Immunol 28: 155-159.

9. Sidky YA, Auerbach R (1975): Lymphocyte-induced angiogenesis: a quantitative and sensitive assay of the graft-vs-host reaction. J Exp Med 141: 1084-1100.

10. Skopińska-Różewska E, Sommer E, Demkow U, et al. (1997): Screening of angiogenesis inhibitors by modified tumor-induced angiogenesis (TIA) test in lung cancer. Acta Medica Bialostociensis 42: 287-296.

11. Chorostowska-Wynimko J, Skopińska-Różewska E, Rogala E, et al. (1998): NON-CD4+ and NON-CD8+ cells are the main source of angiogenic activity of BAL cells homogenates from sarcoidosis patients. Eur Respir J 12 (suppl. 28): 332.

12. He H, Xu J, Warren CM, et al. (2012): Endothelial cells provide an instructive niche for the differentiation and functional polarization of M2-like macrophages. Blood 120: 3152-3162.

13. Martinez FO, Gordon S (2014): The M1 and M2 paradigm of macrophage activation: time for reassessment. F1000Prime Rep 6: 13 .

14. Liu Y, Zou X, Chai Y, Yao Y (2014): Macrophage polarization in inflammatory diseases. Int J Biol Sci 10: 520-530.

15. Tolnay E, Kuhnen C, Voss B, et al. (1998): Expression and localization of vascular endothelial growth factor and its receptor in pulmonary sarcoidosis. Virchows Arch 432: 61-65.

16. Matsuda M, Sakurai K, Fushimi T, et al. (2004): Sarcoidosis with high serum levels of vascular endothelial growth factor (VEGF) showing RS3PE-like symptoms in extremities. Clin Rheum 2004; 23: 246-248.

17. Skopińska-Różewska E, Pastewka K, Wasiutyński A, et al. (2010): The influence of herbal remedies on cutaneous angiogenesis induced in mice after grafting of human kidney cancer tissue. Centr Eur J Immunol 35: 199-203.

18. Rogala E, Skopińska-Różewska E, Wasiutyński A, et al. (2008): Echinacea purpurea diminishes neovascular reaction induced in mice skin by human cancer cells and stimulates non-specific cellular immunity in humans. Centr Eur J Immunol 33: 127-130.

19. Wasiutyński A, Bałan B, Skopińska-Różewska E, et al. (2009): The effect of Echinacea purpurea on the morphology, angiogenic activity and vascular endothelial growth factor (VEGF) concentration of murine L-1 sarcoma tumors. Cent Eur J Immunol 34: 38-41.

20. Radomska-Leśniewska D, Demkow U, Sommer E, (2003): Wpływ destylatu borowiny limanu z dodatkiem kwasu cynamonowego i kumaryny (FIBS) na aktywność angiogenną komórek pochodzących od chorych na sarkoidozę. In: Rola immunomodulatorów pochodzenia naturalnego $\mathrm{w}$ zapobieganiu i leczeniu chorób. Siwicki A, Skopińska-Różewska E, (eds.). Wyd. Medyk, Warszawa 2003; 229-236.

21. Skopiński P, Sommer E, Skopińska-Różewska E, et al. (2001): The effect of coastal salt lake mud distillate mixed 
with cinnamic acid and coumarin (FIBS) on immunological and inflammatory angiogenesis. Terapia 3: 14-15.

22. Radomska-Leśniewska DM, Skopińska-Różewska E, Jankowska-Steifer E, et al. (2010): N-acetylcysteine inhibits IL-8 and MMP-9 release and ICAM-1 expression by bronchoalveolar cells from interstitial lung diseases patients. Pharmacol Rep 62: 131-138.

23. Radomska-Leśniewska DM, Skopiński P (2012): N-acetylcysteine as an antioxidant and antiinflammatory drug and its some clinical application. Cent Eur J Immunol 37: 57-66. 